\title{
Erythroid Burst Forming Unit
}

National Cancer Institute

\section{Source}

National Cancer Institute. Erythroid Burst Forming Unit. NCI Thesaurus. Code C121480.

A unit of viable cell concentration defined as the minimum number of hematopoietic stem cells able to produce a detectable colony of erythroid burst forming cells. 